\title{
The Relationship Between Financial Participation and Other Forms of Employee Participation: New Survey Evidence From Europe
}

\author{
Panu Kalmi \\ Helsinki School of Economics and HECER \\ Andrew Pendleton \\ Business School, Manchester Metropolitan University \\ Erik Poutsma \\ Nijmegen School of Management, Nijmegen University \\ Discussion Paper No. 3 \\ April 2004 \\ ISSN 1795-0562
}

HECER - Helsinki Center of Economic Research, P.O. Box 17 (Arkadiankatu 7), FI-00014 University of Helsinki, FINLAND, Tel +358-9-191-28780, Fax +358-9-191-28781,

E-mail info-hecer@helsinki.fi, Internet www.hecer.fi 


\title{
The Relationship Between Financial Participation and Other Forms of Employee Participation: New Survey Evidence From Europe*
}

\begin{abstract}
This article uses a new data set on the incidence of financial participation in large publiclytraded firms in six European Union countries (Netherlands, France, UK, Finland, Spain, and Germany) to evaluate the possible complementarities between participatory practices. We find evidence that broad-based profit-sharing schemes are related to both direct and indirect participation, but we do not find this for broad-based equity schemes. In fact, broad-based equity schemes are negatively related to indirect participation. Stock option plans appear to be negatively related to all forms of employee participation. Overall, the paper shows that the various forms of financial participation have very different relationships with other forms of employee involvement and participation.
\end{abstract}

JEL Classification: J33, M52, M54

Keywords: Profit-sharing, equity sharing, employee participation in decision-making.

Panu Kalmi

Department of Economics,

Helsinki School of Economics

Po Box 1210

00101 Helsinki

FINLAND

e-mail: panu.kalmi@hkkk.fi
Andrew Pendleton

Business School

Manchester Metropolitan University

Manchester M15 6BH

UNITED KINGDOM

e-mail: a.d.pendleton@mmu.ac.uk

Erik Poutsma

Nijmegen School of Management

P.O.Box 9108

NL-6500 HK Nijmegen

THE NETHERLANDS

e-mail: e.poutsma@nsm.kun.nl

\footnotetext{
* An earlier version of the paper was presented at the workshop "Financial Participation at the Crossroads", organised in Nijmegen in May 2003. The authors wish to thank the participants, especially Darryl D'art and Jim Sesil, for useful comments. The authors also want to thank their collaborators Harry van den Tillaart, Eckhard Voss, Peter Wilke, Robert Tschobanian, Hiro Nohara, Olivier Blacas, Karsten Kruger, Erna Bruin, Fred Huijgen, and Clare Schofield for their participation in the previous stage of the research project. They also gratefully acknowledge a grant from EU commission in the course of the programma Industrial Relations and Social Dialogue. Additionally, Kalmi thankfully acknowledges the Academy of Finland research grant in its LIIKE-programme and a research grant from Marcus Wallenberg Foundation.
} 


\section{Introduction}

The relationship between financial participation and other forms of employee participation have emerged as major issues for European Union institutions, Social Partners, and member governments. ${ }^{\mathrm{i}}$ A recent Communication from the European Commission notes that the benefits of financial participation seem to be greatest when such schemes are introduced through a partnership approach and when they are embedded in an overall approach of participative management (CEC 2002: 19). It further suggested that employees and their representatives should be informed and consulted about the details of financial participation schemes prior to their introduction (ibid: 12). There is now a reasonable body of evidence that is supportive of these claims. Various articles reviewing the empirical evidence (Blinder 1990; Doucouliagos 1995; Jones et al 1997; Kruse and Blasi 1997; Poutsma 2001; Perotin and Robinson 2003) conclude that a complementarity between financial participation and other forms of participation have a beneficial impact on productivity and performance outcomes. Furthermore, the 'determinants' literature has also observed a systematic co-existence of financial participation and direct forms of participation (eg. Festing et al 1999; McNabb and Whitfield 1998; Pendleton 1997). However, evidence on linkages between indirect participation and financial participation is mixed, with some studies finding that financial participation is more prevalent in unionised environments (Gregg and Machin 1988; Pendleton 1997) and with some finding the opposite (Festing et al 1999) or that financial participation is less common in establishments covered by collective bargaining (Heywood et al 1997).

In this paper we explore further the relationships between financial participation and other forms of participation drawing on data collected from listed companies in Finland, France, Germany, the Netherlands, Spain, and the UK. We provide evidence on several important questions. First, what is the incidence of financial participation in the listed company sector? Second, to what extent are other forms of participation related to financial participation? Does the presence of either direct or indirect participation predict the use of profit sharing and employee equity plans? Three, to what extent is employee participation in profit sharing and equity plans influenced by the presence of other forms of participation? 
Our results challenge the view that financial participation and other forms of participation are complementary in the sense that the presence of one facilitates the use of the other. Although there is some evidence of co-existence of profit sharing and other participatory practices, this conjunction is not found with employee equity plans. Neither the use of stock option plans nor stock allocation/acquisition plans are significantly related to either direct or indirect participation. In so far as the evidence elsewhere suggests that complementarity between these forms of participation brings about superior company performance, our results imply that firms in our study may not be realising the full gains of financial participation.

This paper adds to the extant literature in several ways. First, we distinguish more precisely between types of equity plan than is common in many studies: stock option plans are distinguished from other share acquisition plans. Second, we add to the typical analysis of determinants by focusing on employee participation rates as well as plan presence. Although participation rates are clearly highly influenced by company decisions about eligibility, participation in a plan will also be an employeelevel decision. Finally, we extend the analysis to countries that have not featured in financial participation research to date, such as Finland and Spain. Overall, the most important contribution is the evidence that, across a range of countries, employee equity plans do not systematically co-exist with other forms of participation. .

\section{Review of the literature}

The topic of complementarities in the human resource management has received much attention in the recent economics of organisation and industrial relations literature. A series of studies has emphasised the role of 'bundles' of HRM practices, including financial participation, in contributing to superior organisational performance. Some studies have identified forms of financial participation as one practice amongst several that form part of bundles (for example, Ichniowski, Shaw and Prennushi (1997)) whilst others have focused on the relationship between financial participation and other forms of participation, e.g. Ben-Ner and Jones (1995) and Levine (1995). 
There are several reasons why financial participation can be complementary to other forms of participation. Isolated financial participation schemes suffer from the free-rider effect: if employees care only about their personal pay-offs, then groupbased incentive schemes are likely to be ineffective in all but the smallest work environment, since there will always be a temptation to free-ride on other employees (Oyer 2002). However, other participatory schemes may help to create a corporate culture based on co-operation (Weitzman and Kruse 1990) or enhance mutual monitoring (Kandel and Lazear 1992), thereby ameliorating the free-rider problem. Looking at it from the other direction, financial incentives may enhance the effectiveness of work practices such as work teams that rely on the use of employees' 'private' information. The willingness of employees to disclose production-relevant information may be influenced positively by pay-offs provided by instruments such as financial participation (Ben-Ner and Jones 1995; MacDuffie 1995).

The potentially symbiotic relationship between financial participation and other forms of participation is expressed well by Levine and D'Andrea Tyson. They note that,

"sustained, effective participation (in decisions) requires that employees be rewarded for the extra effort which such participation entails, and that they receive a share of any increased productivity or profits...Just as participation can lead to demands for profit sharing, profit sharing can lead to demands for participation. When there is profit sharing, workers' incomes depend on the decisions of the firm, and workers want to have a say in these decisions" (1990: 209).

Further reasons for anticipating a complementarity between financial participation and other forms of participation include the following. One, financial participation plans typically require communication with employees (eg to meet securities regulations), such that firms with prior forms of participation will typically have lower set-up costs (cf Eaton and Voos 1992). Two, a management that is already predisposed to employee participation appears more likely to respond positively to new forms of participation than a management that has no experience or record in this area. Three, a perceived willingness of management to share information and control signals to employees that managerial motives are not opportunistic, whilst the presence of representative institutions may ensure that employees are not exposed to 'hidden' or excessive risk (see Levine 1995). Thus, 
financial participation may be more prevalent and more popular with employees where there are other forms of participation.

Although much of the evidence suggests that financial participation is more likely to have beneficial impacts on performance when other forms of participation are present (Doucoliagos 1995; McNabb and Whitfield 1998; Perotin and Robinson 2003), there is some recent counter-evidence (such as Addison and Belfield's (2000) analysis of the 1998 UK Workplace Employee Relations Survey). The evidence on co-existence between the two, irrespective of performance outcomes is more evenly balanced. Huijgen and Poutsma (1999) found significant correlations between financial participation and direct participation in European countries included in the EPOC survey, and especially in France and the UK, the two countries with the highest incidence of financial participation. However, Festing et al (1999), using data on France, Germany, Sweden and the UK in the CRANET survey, few relationships between direct participation and the presence of either profit sharing or share ownership, though job enlargement and flexibility were related to share plans in France and the UK, and to profit share plans in France.

As for indirect participation, the extant European evidence is mixed and contradictory. Festing et al (1999) found strong inverse associations between union density and equity plans (except in France), and negative but insignificant relationships between density and profit sharing (except in the UK where it was strongly negative). A later study for the European Foundation found weak relationships between union density and both profit sharing and equity plans though union density was significantly inversely related to narrow-based equity plans (Pendleton et al 2001). These pan-European studies contrast with earlier countrybased studies, mainly in the UK, where union density has been positively associated with the use of equity plans, at least up to a point (Gregg and Machin 1988; Pendleton 1997). Meanwhile, evidence from Germany indicates that the presence of works councils is not significantly associated with use of profit sharing, except in those establishments which are covered by an industry-wide collective bargaining agreement (Heywood et al 1997). Further afield, both US and Australian evidence finds weak relationships between profit sharing and union density (Kruse 1996; Drago and Heywood 1995). 
Several limitations can be observed in this literature. First, the type of financial participation is often not clearly distinguished. It is rare for equity-based plans to be separated into their constituent types. For instance, share option and other share acquisition plans are usually grouped together even though they have very different characteristics (the shape of employee risk differs considerably between options-based and other equity-based plans). Furthermore, some studies (eg Festing et al 1999) do not clearly distinguish between broad-based and executive-only financial participation plans. Second, it is uncommon for studies that investigate the relationships between financial participation and other forms of participation to include more than two or three measures of the latter (often because of multicollinearity between participation measures). It is rare for studies to consider the impact of employee involvement in corporate governance on the presence of share plans, even though this form of involvement is potentially important in large listed firms in some European countries. There is an obvious complementarity between employee share ownership (giving control rights) and involvement in corporate governance. Three, with the exception of Drago and Heywood (1995), the influences on the extent of employee participation in financial participation plans has not been considered. Yet, other forms of participation may be critical to high rates of employee participation for both administrative and trust-based reasons.

In this paper, therefore, we examine potential complementarities by exploring the relationship between various forms of participation and financial participation. Three forms of participation are discerned in addition to financial participation itself: representative participation, direct participation, and participation in the establishment and operation of financial participation. We distinguish between profit sharing and equity plans, and, within the equity plan group, between share options and other forms of share acquisition. The empirical strategy in the paper is to examine the relationship between the various forms of employee participation and both the presence of and participation rates in financial participation in listed firms with large market capitalisation. The following questions are posed in the paper.

1. What is the incidence of financial participation in these companies? 
2. To what extent do the various forms of participation co-exist, and do the various forms of decision-making participation predict the use of financial participation?

3. Does the presence of direct and/or indirect participation influence the level of employee participation in profit sharing and equitybased plans?

It will be evident that Questions 1 and 2 refer to decisions that are primarily made by companies and their managers, though these decisions may be influenced by prevailing patterns of employee representation and influence. Question 3, by contrast, refers to some extent to employee-level decisions, though the parameters will be set by managerial decisions about eligibility.

The predicted answer to Question One is that financial participation will be most widespread in those countries where there has been the longest and greatest support for financial participation (see Pendleton et al 2002). Thus, profit sharing will likely be most widespread in France, where one form of profit sharing has been compulsory for firms with more than 50 employees for some considerable time. Profit sharing is also expected to be widespread in Germany due to its integration with long-standing employee savings and wealth distribution instruments (Carstensen et al, 1995), and possibly as an alternative to equity-based instruments (given the relatively small size of the German stock market). Share ownership plans are expected to be most prevalent in the UK, where legislation to promote share plans has been in operation for twenty-five years. The average age of financial participation plans is likely to reflect the longevity of legislation and fiscal concessions. Furthermore, we anticipate that many financial participation plans in countries other than France and the UK will be of very recent progeny.

As for Question Two, we predict that the presence of financial participation will be associated with the use of direct participation for the types of reasons considered earlier. Complementarity between the two is likely to raise returns whilst lowering set-up costs. Furthermore, the managerial decision to establish a financial participation plan may well reflect beliefs about the efficacy of employee involvement that will also lead to the use of forms of direct involvement. Predicting the 
relationship between financial participation and indirect participation is less clear-cut. On the one hand, a complementarity may be expected for the same reasons as proposed in relation to direct participation. On the other, suspicion of financial participation by some employee representatives where representation is present may constrain managerial capacities to use financial participation. Alternatively, those firms where representation is absent may be run by owners and managers who are well-disposed to financial participation. In other words, absence of representation and support for financial participation may flow from a common managerial ideology that emphasises common interests. These observation raise a more general issue as to whether financial participation might be a substitute for other forms of participation, and vice-versa. It is arguable that some countries have made relatively less use of financial participation than others because they have developed alternative means of securing employee consent and commitment. If a country has a well-developed works council system, for instance, does it need employee equity plans?

It is difficult to provide a clear prediction for Question Three. On the one hand, participation rates could be positively associated with indirect representation such as trade union committees because these forms of representative participation provide protection (real and perceived) against risk and managerial opportunism. The relationship is likely to be stronger in the case of share purchase plans than share options because the level of risk to employees is more immediate. On the other hand, participation rates in equity plans may be negatively associated with indirect participation because these plans are likely to be a more central feature of companies without 'traditional' forms of employee representation, with the result that employees are more likely to subscribe in such companies. Or, given risk aversion amongst employees, employees in high indirect participation firms may use their decisionmaking power to limit the use of these plans. Direct participation is likely to be positively associated with share ownership participation (both options and share purchase plans) because provision of employee involvement will encourage a hightrust work environment that will be conducive to employee subscription to the share plan. Employee involvement in the design, introduction, and administration of share plans may positively influence employee participation in the share plan because of protection against managerial opportunism. 


\section{Data}

To address these questions we utilise a dataset collected from a sample of publicly traded firms in six European Union member countries: Finland, France, Germany, Netherlands, Spain, and the UK. These countries represent the main geographical areas of the European Union. They also provide examples of countries where the use of financial participation has been longstanding (France, UK), where it has become more popular recently (Finland, Germany, and the Netherlands), or where the use remains low (Spain). We concentrate on listed firms because previous work has indicated that listing is a very powerful influence on the incidence of share-based financial participation (Pendleton et al 2001).

The sampling frame was 869 stock-market listed firms (see Table 1). For the two smaller lists, Helsinki and Amsterdam, we contacted all companies in the stock exchange. In other countries, the sample was drawn from the largest 200 companies by market capitalisation. In the UK, the sampling frame was the FTSE 100 in its entirety plus a random sample of firms within the main market sectors (except investment companies) in the FTSE 350. In Germany the listed companies from the prime standard are contacted (except investment companies). In France the top 100 companies were selected (CAC40 plus a selection). In Spain the top 100 of BME were selected (Barcelona and Madrid). In all cases the contact details of the person responsible for financial participation or the HRM manager are gathered. In some cases we were not able or allowed to gather this information. This led to a slightly lower number of potential respondents. This approach leads to some overrepresentation of Finland and the Netherlands in the final dataset. France and Spain is under-represented.

Table 1 about here

Information was collected using a structured questionnaire sent to the person responsible for managing financial participation or to a senior human resource manager responsible for employee rewards. The questionnaire was designed to collect information on financial participation plans and other forms of employee participation. The study focuses on national financial participation plans, and we did not include questions on global equity plans. Information was collected on both 
consultative and delegative forms of participation (see Huijgen and Poutsma 1999) as well as on indirect participation and employee involvement in governance. Information on union density was not sought because this measure (of union presence or power) does not have uniform implications between countries due to variations in institutional contexts ${ }^{\text {ii }}$.

The response rate overall was 29.5 per cent, with the lowest national rate being 18 per cent in Spain, and the highest levels in the Netherlands and in the UK. The data may suffer from selection bias in so far as firms with financial participation may be disproportionately likely to respond. Given the lack of comprehensive national statistics of the incidence of financial participation in some countries this cannot be ruled out. However, at some points our data also understates the real incidence of schemes. For instance, it is known that in Finland over 75 per cent of publicly listed firms have stock option schemes (Jones, Kalmi and Mäkinen 2004), while our data suggests that only 55 per cent of firms have stock option plans. Apart from potential sampling error, it may be that some Finnish firms that have only managerial schemes have not indicated their scheme in their response, and the same has probably happened in other countries as well. With these cautions about the degree of representativeness of the respondents, we believe that the data gives a good picture of participation practices in the upper reaches of the listed company sector in each country.

\section{Results:}

\section{i) the incidence of financial participation}

As is shown in Table 2, a financial participation plan is found in over 80 per cent of listed companies in all countries, except Spain where the figure is just over 40 per cent. Share schemes are more common than profit-sharing schemes: almost 70 per cent of respondents have an equity scheme, while slightly over 50 per cent of respondents have a profit-sharing scheme. Stock option plans are widespread, with over 60 per cent of respondents having such a plan. This does not mean that the use of other share plans, such as stock purchase arrangements, is confined to the residual between all schemes and stock option schemes. Most respondents with equity 
schemes have more than one scheme. 122 respondents have an equity scheme other than stock options, but of these 101 appear together with stock options (not shown in the table). Over 85 per cent of respondents have either an equity scheme or a profitsharing scheme.

Table 2 about here

The above notwithstanding, broad-based profit-sharing schemes are slightly more common than broad-based equity schemes. This is because profit-sharing schemes are almost always broad-based, while a significant proportion (around onethird) of equity schemes are not. As predicted, the highest incidence of broad-based profit sharing is found in France, where legislation to promote this form of financial participation is long-standing. Apart from Spain, the incidence of broad-based profit sharing is similar between countries, ranging from just under 40 per cent to 50 per cent. The results for broad-based share plans also fit with institutional explanations: share plans are most prevalent in the UK, where there has been long-standing legislation to promote this form of financial participation. The UK also has the highest incidence of stock options plans, though not all of these are broad-based

As for the number of schemes per country, here the two leading countries are the UK and France. In both countries, the average listed firm has over 2 schemes. However, this may be partly due to national characteristics of the schemes. For instance, if profit-shares are partly distributed as shares, the plan may be counted twice. We are able to check this in most cases and can confirm that the same reward is not double-counted. However, we cannot be sure that this is so in every case so double-counting cannot be entirely ruled out.

Table 3 about here

Table 3 contrasts sharing plans according to average age by country, and as can be seen there are substantial differences.. Profit sharing schemes tend to be older than equity plans, with the oldest profit share programme being over 100 years old and about a quarter of them being over 20 years old. They are a more recent 
phenomenon in Finland, where they became common only during the 1990s, and in Spain, where they are rare. As for equity plans, they tend to be long-standing in France, Germany and the UK, whilst they are younger in in Finland and in the Netherlands. Within the equity plan grouping, stock option plans are mainly of recent progeny, except in the case of the UK and France. Stock options plans became more common from the late 1990s in some European countries, such as Germany (where the KonTrac legislation in 1998 removed legal constraints) and Finland. It is notable that 60 per cent of the German firms have stock options: this indicates very rapid growth since legalisation.

\section{ii) The relationship between forms of participation and financial participation}

In the next stage of the analysis, the focus is on the relationship of direct and indirect participation with financial participation. Specifically, the intention is to determine to what extent forms of participation predict the use of financial participation. Altogether, seven forms of participation are considered in addition to financial participation, and these were selected to reflect indirect and direct participation. Indirect participation items are the presence within the firm of a trade union committee, a works council or joint consultative committee, and employee representation on the company board. Direct items are employee surveys, suggestion schemes, quality circles, and teamwork. The means of these variables, and the correlations between them, are shown in Table 4 .

Table 4 about here.

Table 4 provides support to the idea that the various participatory practices are complements. Of the 21 pairwise correlation coefficients, 16 are positive and significant, and 5 are insignificant. There are no significant negative correlations. This indicates a high degree of correlation between variables. Furthermore, the withingroups correlations (ie within the direct and indirect participation 'groups') are stronger than between-groups correlation. This can be seen most clearly in relation to works councils: these are strongly correlated with union committees and board representation, but only weakly or not at all with direct participation. In contrast, board representation correlates strongly with all other variables except for teams. 
Teams have zero correlations with indirect participation but they are strongly correlated with other direct participation practices. The highest correlation coefficient is between quality circles and suggestion schemes $(r=0.49)$.

Given the extent of correlation between the participation variables, the issue arises as to how to deal with these in multivariate analysis. Four possible ways can be considered, each with strengths and weaknesses. The first is to enter each participatory variable into a regression equation separately so that we can assess the individual effects of each. However, there are major drawbacks. Entering the variables individually does not reveal anything about complementarities (or interactions) between variables. Use of interaction terms to overcome this problem is precluded by the difficulties of interpretation when several such terms would need to be included. A further major problem is the likely extent of multicollinearity given that some participatory practices appear to co-exist.

Another possibility is to bundle the participatory practices using some ideal types of participation, e.g. high involvement, collective bargaining, and authoritarian workplaces (see e.g. Fernie and Metcalf 1995). However, such categorisations, while arguably based on theory, often have an ad hoc - flavour. Moreover, the fact that we have data on six countries with very different industrial relations systems makes it very difficult to find categories that could be equally applicable to each individual country. A third possibility is to use summated scale indices (as in MacDuffie 1995). While this has the virtue of simplicity, it suffers from assigning, somewhat arbitrarily, an equal weight to each practice. We present such scales and information on the incidence of participatory practices by country in Appendix One but do not use these indices in the regressions because of this limitation.

A fourth possibility - and the one we adopt - is to use principal components analysis (PCA). PCA is a statistical technique that linearly transforms a set of variables into a smaller set of uncorrelated variables, whilst retaining the information incorporated in the original variables (e.g. Dunteman 1988). It is the most robust statistically of these four options, and for this reason has been used elsewhere in the high performance work practice literature (eg Huselid 1995). It has some particular advantages for our purpose. Of the four approaches, the notion of complementarity is 
most easily incorporated in the PCA approach. An initial test for complementarity is whether the variables load positively onto the first principal component (Laursen and Foss 2003). Second, the PCA also enables us to examine whether the conceptual distinction between indirect and direct forms of participation also holds empirically, and whether certain practices are complementary or substitutes. While most of the literature cited above implies that various participatory practices are complementary, a plausible alternative hypothesis that they are substitutes could also be formulated. For instance, does employee board representation reduce the need for unionisation, since employees interests are already represented (in which case board representation and unions are substitutes), or does effective board representation require union support to be effective (complements)?

Table 5 about here

Table 5 shows the loadings of the various principal components. All variables load positively to the first component, quality circles and suggestion schemes getting the highest loadings. This supports the view that there are complementarities between various forms of participation, and the first component can also be interpreted as an indicator of "general participation". In the second component, the indirect forms of participation load positively while the direct forms of participation load negatively. This component can be interpreted as a contrast between indirect and direct participation. We choose to retain the two first components that capture around 50 per cent of the total variance. While retaining the two first components is consistent with the "Kaiser criterion" that recommends dropping those components that have eigenvalues less than one (Dunteman 1988, p. 22), these two components are also the easiest to interpret given the distinction between direct and indirect participation, and the role of complementarities, in our prior conceptual framework. The regression values of these factors are computed and then used in the probit analyses.

To evaluate the role of participation, we mount probit estimations of the determinants of various forms of financial participation, with these factor scores being included as independent variables. We also include several control variables. The natural log of employment is the measure of firm size. It should be noted that 
although the sample basis was size by market capitalisation, the inclusion of high value smaller firms (eg bio-technology firms) means that there is greater variation in employment size than might be expected $($ mean $=13654$, standard deviation $=$ 27,541) $)^{\mathrm{iii}}$. Employment size is expected to have two contradictory effects. On the one hand, economies of scale in scheme set-up and administration suggest a positive relationship. One other hand, the free-rider effect suggests a negative relationship between employment size and financial participation. A related argument is that the "team spirit" or effective communication channels that may be necessary complements for the effective use of sharing plans are more readily cultivated in smaller firms (Weitzman and Kruse 1990; Ben-Ner et al. 2000). Since our data consists entirely of listed firms that would be expected to have expertise in accounting and personnel management (in response to regulatory pressures), we anticipate that the free rider issues might predominate, thereby leading to a negative relationship between size and plan presence.

We also control for the relationship between different forms of financial participation. There is evidence from Japan and from the US that firms may operate more than one type of financial participation scheme simultaneously (Jones and Kato 1995; Freeman and Dube 2001). It is worth noting that while profit-sharing and equity schemes are often lumped together as "financial participation", they may operate to a quite different logic. Profit-sharing is based on accounting figures and thus reflects past performance. The returns to equity schemes, in turn, depend on share price performance and reflect expectations on future performance. In our data, the coexistence of profit-share and equity plans sometimes results from the fact that profitshares are paid at least partly in equity: this is the case especially in France and in the UK. As noted earlier, we cannot fully distinguish between cases where equity awards are part of a profit sharing plan and cases where the two schemes operate separately. However, this shortcoming is not critical because the decision to pay out profit shares in equity indicates more 'advanced' financial participation than where profit shares are paid in cash (though possibly in deferred form, as in France) ${ }^{\mathrm{iv}}$

Finally, dummies are included for each country in our analysis (UK being the omitted category), for information and communication technologies (ICT) firms, and for services (manufacturing being the omitted category). Our expectations related to 
country dummies are based on previous cross-European research, as well as the results presented earlier, that has suggested that broad-based schemes are common especially in France, with its mandatory profit-sharing, and in the UK, where share schemes are common (Pendleton et al. 2001, Poutsma and de Nijs 2003). We expect equity schemes to be most common in ICT, where stock options especially are known to be widely used (Ittner, Lambert and Larcker 2003) because (young) employees are assumed to be risk-positive, there is a pronounced need to lock-in unique human capital, and there are often liquidity problems for the firm. Financial participation is predicted to be more prevalent in services rather than manufacturing environments due to the nature of work tasks (eg. less easily measured) and the nature of the workforce.

We use two complementary approaches in our investigation on the financial participation schemes. First, we use probit to examine whether the firm has a broadbased profit-sharing or equity plan, using the 50 per cent participation rate as a cutoff. Second, we use OLS regressions to examine employee participation rates. We include into the second set of regressions additional variables based on information that applies only to firms with financial participation. These are employee participation in the design of the scheme, and the relative performance of the firm upon the adoption of the scheme. In the specification containing equity schemes, we also add dummy variables for the availability of tax reliefs.

Table 6 about here

Table 6 shows the results of the probit analysis. We estimate separately the probabilities of having broad-based profit-sharing and broad-based equity schemes. ${ }^{\mathrm{v}}$ The criterion for "broad-based" is a positive response to a question asking whether plans are broad-based, supplemented with a 50 per cent or higher participation rate. The effects reported in the table are the probit marginal effects, which denote the expected increase in the probability (measured in the percentage units) that the firm has a broad-based scheme, when the relevant dependent variable changes by one unit (and all other variables are held constant). We calculate the expected probability by holding all variables, expect for the number of employees, at zero. ${ }^{\text {vi }}$ Thus, the reference firm is a UK manufacturing firm with average participation and without a 
broad-based equity scheme. For such a firm, the expected probability of observing a broad-based profit sharing plan is 35.5per cent. If the firm happened to be French (i.e. the dummy French would obtain the value 1) the expected probability increases by 55 percentage units. In contrast, if the firm were Spanish, the expected probability decreases by 30 percentage units.

However, the more interesting results relate to other variables. The simultaneous presence of a broad-based equity plan increases the likelihood of observing a broad-based profit-sharing plan by 12 percentage units. There are significant effects from the participation variables as well. A one standard deviation unit increase in general participation increases the probability by 5 percentage units, and a corresponding increase in the second component also increases the probability by 5 percentage units (though the latter is not quite significant at 10 per cent). The interpretation of these results is that there is indeed evidence on complementarities, that the use of broad-based profit-sharing increases with the use of other participatory practices, and that this increase is more strongly related with the use of indirect participation practices than direct participation practices. These results are consistent with the descriptive results found in Appendix One, where participation indices get higher values in firms with profit-sharing schemes than in those that did not have profit-sharing, and where the differences were more pronounced for indirect than direct participation. ${ }^{\text {vii }}$

A further significant result in Table 6 relates to the number of employees. A unit increase in the log of employment (which corresponds to a 170 per cent increase in ordinary scale) increases the probability of observing a broad-based profit-sharing scheme by over 5 per cent. ${ }^{\text {viii }}$ This indicates that larger firms are more likely to adopt profit-sharing plans. In contrast, the industry dummies are not significant.

Turning to the determinants of broad-based equity plans, we see that the country dummies get negative values and three of them (Netherlands, Finland and Spain) are significant. Broad-based equity plans are clearly more common in the UK than in other countries. The presence of a broad-based profit share plan also increases the likelihood of observing a broad-based equity plan by 12.5 per cent. The participation indices get negative signs, but both of them are insignificant. The use of 
equity plans thus seems to be independent of other forms of participation. ICT firms have a 20 percentage units higher probability of having a broad-based equity scheme than manufacturing firms, whilst the probability does not differ between service and manufacturing firms.. The effect of the number of employees is the reverse compared to the effect in profit-sharing firms: here a one log-unit increase in the number of employees decreases the probability of observing a broad-based equity scheme by 5 percentage units.

We also examine more specific forms of share plans: share acquisition and stock option plans. We cannot clearly separate out firms with these two forms of share plans: a substantial number of share plan firms have both forms. Nevertheless, the results indicate some differences in predictors. In the results for share acquisition plans, all of the country dummies become significant. In combination with the significant effect of profit sharing, this suggests that the results are picking up the UK Approved Profit Sharing scheme (which allocates shares to employees, resourced by profits). By contrast, stock option plans operate independently of profit sharing and are strongly predicted by the ICT dummy and the size measures. However, in both instances, the participation measures are not significant, and this reinforces the results for share plans as a whole. Also of note is that general participation is negatively related (though not significantly) to stock options.

To sum up the findings from the Table 6, it appears that profit-sharing is strongly related to participation, and to indirect participation more than direct participation. However, we do not find any links between equity schemes and participation in decision-making. The country effects are also consistent with the results presented earlier, and reinforce the importance of national institutional and legislative contexts.

\section{iii) Employee participation in financial participation plans}

The final stage of the analysis is concerned with the determinants of employee participation rates in broad-based financial participation, and specifically whether other forms of employee participation have a positive effect on these. We anticipate positive effects on the grounds that these other forms of participation will add to a participatory culture and generate trust. All things being equal, these considerations 
should be more important for equity plans than for profit sharing because the former typically require employees to invest or at least to explicitly 'opt-in' to the plan (because of regulatory requirements).

Table 7 provides descriptive statistics for employee participation rates in the various forms of financial participation. Average participation rates in profit sharing are above 75 per cent in all countries other than Spain, with the median rate being 100 per cent or just under four of the six countries. Clearly, nearly all profit sharing plans have very high participation rates. By contrast, the average participation rate in share plans is much lower, with a mean in four countries of just over 50 per cent, and a median participation rate of a similar order. Spain again has a lower participation rate, and France has a higher participation rate.

Table 7 about here

In this part of the analysis we include additional independent variables. We control for the recent performance of the firm, on the grounds that higher performance is likely to stimulate higher participation, either because it may lead to larger profit share pay-outs or may boost the valuation of the listed company. This is a reverse argument to the typical causal path in the literature which postulates that financial participation causes superior performance ${ }^{\mathrm{ix}}$. An alternative argument is that in equity plans, prudent employee investors will participate when performance is below par on the basis that substantial gains might be made. This is especially so for option plans where downside risk is minimised. Past performance was measured on a three-point scale where 1 indicates lower than average performance, 2 is average performance, and 3 is above average performance upon adoption. Since very few respondents indicated that their performance was below average, the variable was recoded into a dummy with the value 1 if performance was above average and 0 otherwise.

We also include controls for the use of tax breaks for employees and employers, where $1=$ the presence of a tax break, 0 otherwise. The expectation here is that tax breaks, especially those for employees, are positively linked with participation rates. 
We expect that employee participation in the management of financial participation will positively affect employee participation rates because of the protection apparently provided against hidden risk and managerial opportunism. The variable used is a five-point scale measuring the extent of employee participation in the development of the financial participation plan.

Since the dependent variable is a continuous measure (though truncated at 0 and 100), ordinary least squares is used to assess the determinants of the employee participation rate, and the results are shown in Tables 8 and 9. Two sets of specifications are shown: one where the independent variables are the same as those in stage two of the analysis (Table 8), and a second that incorporates the additional variables described above (Table 9). The new variables included in Table 9 have a value only if a plan is present, so the number of observations in the regressions is lower than in Table 8. A weakness of the OLS method in this context is that many observations are concentrated at the ends of the distribution, with the result that the standard errors may get overly large, thereby reducing the statistical significance of our findings. This is more of a problem with the profit-sharing equations because participation tends to be more or less uniformly high. Therefore, the results should be interpreted with care. ${ }^{\mathrm{x}}$ A further limitation of this analysis is that we do not have any direct information on the characteristics of employees and that we have to use rather broad proxies (e.g. industry sector) to capture these.

Tables 8 and 9 about here

The results for the first specification are similar to those presented in Table 6 . The France dummy increases the participation rate in broad-based profit-sharing, compared to the UK, by 55 percentage units, as is to be expected given compulsory all-employee profit sharing in France. A log-unit increase in the number of employees increases the participation rate by 4 per cent. A standard deviation- unit increase in general participation increases the participation rate by around 5 percentage units. However, the impact of the contrast between indirect and direct participation is not significant. Also the impact of the participation rate in equity schemes remains insignificant. However, as discussed above, the inflation of standard errors due to the statistical problems discussed above may cause insignificance. 
In column 5 (Table 9) we present the results for profit-sharing with the additional explanatory variables. In this model, general participation becomes insignificant, but the new variable recording employee participation in plan management is strongly significant. The direction of causality is not entirely clear. In the model, more participation in plan development leads to higher participation rates, perhaps via the effect that employees are more willing to participate in plans they have helped to create. However, a plausible alternative scenario is that managers decide that the scheme covers the entire workforce, and when this decision is made, the managers allow (or encourage) employees to participate in plan development. There may be a French effect at work: employee participation in development is substantially higher on average in France, and this may reflect the requirement for explicit employee consent to profit sharing plans in French legislation.

In column 2 (Table 8) the results for equity scheme participation are shown. As could be expected, several of the country dummies are significant. Also the industry dummy ICT is significant and large at 27 per cent, indicating that ICT firms typically operate inclusive schemes. A log-unit increase in the number of employees decreases the participation rate by 2.5 per cent. Interestingly, the second participation component is negative and significant, while the first component is insignificant. Although participation in general appears to be unrelated to the participation rates in equity schemes, there is evidence that representative participation inhibits the participation in equity. This is consistent with hypothesis that employees may oppose equity schemes when they have a say, perhaps due to the risk involved in them. It also suggests that employee participation is not dependent on the provision of voice mechanisms to protect their investments.

Column 6 adds the further variables. The significant negative coefficients on the country dummies in Column 2 become insignificant (though France becomes significantly positive at 10 per cent) but the employee tax relief variable is positive at 10 per cent. Some of the country effects are likely to be channelled into the tax effect. The performance effect is negative (though insignificant) suggesting that employees are sound investors. Most important for our purposes, the measure for employee participation in plan management is not significant, suggesting that this form of 
protection is not critical for high employee participation or for highly inclusive equity plans. Furthermore, indirect participation continues to be negative and significant.

Columns 3 and 4, and then 7 and 8 , examine the determinants of high participation rates in specific types of equity plan. Country dummies are significant for the restricted specification for share acquisition plans though some of these become insignificant when employee tax reliefs are added in Column 7. Participation in profit sharing plan has similar effects in the two specifications, and this result suggests that the UK Approved Profit Sharing plan is being picked-up here. Employee participation in all forms is insignificant in both specification 3 and 7.

The stock option results (Columns 4 and 8) are somewhat different from the stock acquisition plan results. Country effects are less pronounced in the restricted specification and are insignificant in the full specification. The ICT dummy is most powerful in both equations and there are also significant negative size effects. Employee participation is not apparently dependent on tax concessions. The most important result for our purposes is that all forms of participation are negatively related to employee participation in stock options, with the contrast between indirect and direct participation being significant in both specifications. These results suggest that stock options in particular do not form part of a participative work culture. We may speculate that broad-based stock options are used for rather different purposes than employee involvement, such as providing rewards where there are liquidity constraints on the firm.

\section{Conclusions}

In this paper, we have used data from listed firms in six EU countries to investigate the relationship between several types of financial participation and various other forms of employee participation. Overall, our expectation was that these other forms of participation would form complementary relationships with financial participation, as the literature tends to predict. The most important result generated by the study is that there are substantial differences between types of financial participation in this respect. Whereas profit sharing is accompanied by other forms of participation, 
including indirect participation and employee involvement in plan management, companies with equity-based plans tend to be less participative in every respect. This is particularly pronounced in the case of stock option plans.

We can think of three possible explanations for the profit sharing results. The first is that country-specific participation effects are embedded in the results. The high incidence of profit sharing in France, coupled with high levels of indirect participation relative to direct participation, may be partly responsible. The finding that employee involvement in plan development has significantly positive effects on employee participation rates may reflect the requirements in French profit sharing legislation that plans have to be agreed by employees or their representatives. This explanation has some credence though it should be borne in mind that French companies have very low incidence, compared to companies in the other countries, of direct participation, and we would expect to find this reflected in the overall results for participation if a French effect is at work.

A second, more general, explanation is that the high rates of participation in profit sharing plans complement other forms of participation with equally wide coverage to a much greater extent than share plans, where participation is often much lower (because employees typically have to opt-in rather than opting-out). The immediate effects of profit sharing, compared with the deferred character of sharebased rewards, may be more conducive to applying 'reinforcement' effects to cooperative employee behaviour in other arenas of employee participation. This explanation has some force but it should be borne in mind that we in effect control for levels of employee participation in financial participation plans, and that the negative results for other forms of employee participation apply to equity plans where participation rates are high.

A third, general explanation is that profit sharing is more complementary to indirect representation than equity based plans because it has much closer linkages to core employee remuneration. Profit shares, except when paid in shares, are paid from the wages budget and provide cash supplements to wages or cash contributions to saving plans. Since employee wages are typically subject to collective bargaining in many large European firms, profit sharing seems likely to come into the ambit of 
collective bargaining, even where it is designed to bring about greater flexibility in pay and pay determination. Even where profit sharing is not formally subject to collective bargaining, it may be stipulated as an issue for works councils, as in Germany. By contrast, equity plans in most cases are formally distinct from wages and are governed separately by securities regulations. We would not expect therefore the same degree of complementarity with indirect participation. Ironically, the main exception to this is stock option plans where in young, liquidity-constrained ICT firms, options have functioned as pay substitutes. The nature of these firms is that they tend not to possess institutions of employee representation for a variety of reasons.

Nevertheless, the lack of a strong or clear relationship between direct (usually employer-initiated) participation and equity plans remains something of a puzzle given existing theory. We expect plans to be more prevalent, and employees more likely to participate in them, where there are other forms of employee involvement. These results suggest that equity plans operate to a different logic. One may be the availability of tax breaks: firms use equity plans to make tax breaks available to workers. These tax breaks may provide a sufficient degree of risk premium or insurance to generate high employee participation even in the absence of institutions to protect their investments. Unfortunately, we are not able to investigate such possibilities further as we lack both employee data and information on company characteristics other than the participation arrangements. Future research needs to add this kind of data to further our understanding of the relationship between financial participation and other forms of employee participation. 
Table 1 Number of respondents in each country

\begin{tabular}{|l|l|l|l|l|}
\hline Country & Initial sample & $\begin{array}{l}\text { Number of } \\
\text { responses }\end{array}$ & Response rate & $\begin{array}{l}\text { Respondents } \\
\text { as } \\
\text { percentage } \\
\text { of all } \\
\text { responses }\end{array}$ \\
\hline Netherlands & 180 & 70 & 38.9 & 27.3 \\
\hline France & 114 & 30 & 26.3 & 11.7 \\
\hline UK & 169 & 56 & 33.1 & 21.9 \\
\hline Finland & 145 & 42 & 29.0 & 16.4 \\
\hline Spain & 94 & 17 & 18.1 & 6.6 \\
\hline Germany & 167 & 41 & 24.6 & 16 \\
\hline Total & 869 & 256 & 29.5 & 100 \\
\hline
\end{tabular}


Table 2 Incidence of profit-sharing, options or share ownership by country Percentages of firms (except where shown)

\begin{tabular}{|l|l|l|l|l|l|l|l|}
\hline & Netherlands & France & UK & Finland & Spain & Germany & Total \\
\hline $\begin{array}{l}\text { Profit- } \\
\text { sharing (all } \\
\text { forms) }\end{array}$ & 47.1 & 83.3 & 51.8 & 57.1 & 11.8 & 48.8 & 52.0 \\
\hline $\begin{array}{l}\text { Broad- } \\
\text { based } \\
\text { profit- } \\
\text { sharing }\end{array}$ & 38.6 & 83.3 & 50.0 & 50.0 & 5.9 & 41.5 & 46.5 \\
\hline $\begin{array}{l}\text { Share } \\
\text { schemes } \\
\text { (all forms) }\end{array}$ & 64.3 & 63.3 & 89.3 & 57.1 & 41.2 & 80.5 & 68.5 \\
\hline $\begin{array}{l}\text { Stock } \\
\text { options }\end{array}$ & 60.0 & 56.7 & 78.6 & 54.8 & 35.3 & 61.0 & 61.3 \\
\hline $\begin{array}{l}\text { Broad } \\
\text { based share } \\
\text { schemes } \\
\text { (including } \\
\text { options) }\end{array}$ & 37.1 & 46.7 & 64.3 & 35.7 & 11.8 & 48.8 & 44.1 \\
\hline $\begin{array}{l}\text { Proportion } \\
\text { of firms } \\
\text { with at } \\
\text { least one } \\
\text { scheme }\end{array}$ & 82.9 & 90.0 & 94.6 & 85.7 & 41.2 & 92.7 & 85.5 \\
\hline $\begin{array}{l}\text { Proportion } \\
\text { of firms } \\
\text { with a } \\
\text { broad- } \\
\text { based } \\
\text { scheme }\end{array}$ & 57.1 & 80.0 & 66.1 & 66.7 & 11.8 & 56.1 & 60.2 \\
\hline $\begin{array}{l}\text { Average } \\
\text { number of } \\
\text { schemes }\end{array}$ & 1.31 & 2.03 & 2.16 & 1.48 & 0.65 & 1.59 & 1.61 \\
\hline $\begin{array}{l}\text { Percentage } \\
\text { of broad- } \\
\text { based } \\
\text { schemes of } \\
\text { all schemes }\end{array}$ & 76.9 & 88.9 & 69.8 & 77.8 & 28.6 & 60.5 & 70.3 \\
\hline
\end{tabular}

Notes: 1) One firm may have multiple schemes. 2) The respondent is classified having a broad-based scheme if it has at least one scheme where at least $50 \%$ of its employees participate. 
Table 3 Age of financial participation plans

Means, (standard deviation), median, and (number of observations)

\begin{tabular}{|l|l|l|l|l|l|l|l|}
\hline & Netherlands & France & UK & Finland & Spain & Germany & All \\
\hline Age, & 15.84 & 19.13 & 11.41 & 5.71 & 5 & 20.21 & 14.45 \\
profit & $(9.61)$ & $(11.84)$ & $(8.17)$ & $(3.55)$ & $()$. & $(24.51)$ & $(13.59)$ \\
sharing & 12 & 16 & 15 & 5 & 5 & 10 & 11 \\
schemes & $(31)$ & $(23)$ & $(22)$ & $(21)$ & $(1)$ & $(19)$ & $(117)$ \\
\hline Age, & 4.56 & 22.80 & 8.21 & 2.78 & 4.50 & 8.60 & 9.04 \\
share & $(3.50)$ & $(16.36)$ & $(8.86)$ & $(1.86)$ & $(3.53)$ & $(11.28)$ & $(11.15)$ \\
schemes & 4 & 21 & 6.5 & 2 & 4.50 & 3 & 5 \\
& $(9)$ & $(10)$ & $(28)$ & $(9)$ & $(2)$ & $(20)$ & $(78)$ \\
\hline Age, & 6.33 & 9.80 & 10.34 & 2.18 & 3.40 & 1.48 & 5.80 \\
stock & $(5.09)$ & $(10.35)$ & $(7.77)$ & $(1.47)$ & $(4.28)$ & $(0.82)$ & $(6.32)$ \\
option & 4 & 6 & 9 & 2 & 2 & 2 & 3 \\
schemes & $(39)$ & $(5)$ & $(35)$ & $(22)$ & $(5)$ & $(25)$ & $(131)$ \\
\hline
\end{tabular}


Table 4 Means (standard deviations) and Pearson correlation coefficients between the participation variables

\begin{tabular}{|c|c|c|c|c|c|c|c|c|}
\hline Variable & $\begin{array}{l}\text { Means } \\
\text { (s.d.) }\end{array}$ & $\begin{array}{l}\text { Trade } \\
\text { union }\end{array}$ & $\begin{array}{l}\text { Works } \\
\text { council } \\
\text { or other }\end{array}$ & Board & $\begin{array}{l}\text { Employee } \\
\text { survey }\end{array}$ & $\begin{array}{l}\text { Suggesti } \\
\text { on } \\
\text { scheme }\end{array}$ & $\begin{array}{l}\text { Quality } \\
\text { circle }\end{array}$ & $\begin{array}{l}\text { Team- } \\
\text { work }\end{array}$ \\
\hline $\begin{array}{l}\text { Trade union } \\
\text { committee }\end{array}$ & $\begin{array}{l}0.39 \\
(0.49)\end{array}$ & 1.00 & & & & & & \\
\hline $\begin{array}{l}\text { Works } \\
\text { council or } \\
\text { similar } \\
\text { committee }\end{array}$ & $\begin{array}{l}0.76 \\
(0.43)\end{array}$ & $0.23 * * *$ & 1.00 & & & & & \\
\hline $\begin{array}{l}\text { Board } \\
\text { representati } \\
\text { on }\end{array}$ & $\begin{array}{l}0.26 \\
(0.44)\end{array}$ & $0.16^{* * *}$ & $\begin{array}{l}0.22 * * \\
*\end{array}$ & 1.00 & & & & \\
\hline $\begin{array}{l}\text { Employee } \\
\text { survey }\end{array}$ & $\begin{array}{l}0.38 \\
(0.49) \\
\end{array}$ & $0.12 *$ & -0.01 & $0.21 * * *$ & 1.00 & & & \\
\hline $\begin{array}{l}\text { Suggestion } \\
\text { scheme }\end{array}$ & $\begin{array}{l}0.42 \\
(0.49)\end{array}$ & $0.18 * * *$ & 0.05 & $0.24 * * *$ & $0.26 * * *$ & 1.00 & & \\
\hline $\begin{array}{l}\text { Quality } \\
\text { circle }\end{array}$ & $\begin{array}{l}0.32 \\
(0.47)\end{array}$ & $0.19 * * *$ & $0.12 *$ & $0.26 * * *$ & $0.28 * * *$ & $0.49 * * *$ & 1.00 & \\
\hline Teamwork & $\begin{array}{l}0.30 \\
(0.46)\end{array}$ & -0.01 & -0.05 & 0.03 & $0.15 * *$ & $0.26 * * *$ & $0.28 * * *$ & 1.00 \\
\hline
\end{tabular}

Significance levels: *** $-1 \%, * *-5 \%, *-10 \%$.

$\mathbf{N}=\mathbf{2 4 5}$ 
Table 5: Principal components of the participation variables: Eigenvectors

\begin{tabular}{|l|l|l|l|l|l|l|l|}
\hline Variable & $\begin{array}{l}\text { Eigenvector } \\
1\end{array}$ & $\begin{array}{l}\text { Eigenvector } \\
2\end{array}$ & $\begin{array}{l}\text { Eigenvector } \\
3\end{array}$ & $\begin{array}{l}\text { Eigenvector } \\
4\end{array}$ & $\begin{array}{l}\text { Eigenvector } \\
5\end{array}$ & $\begin{array}{l}\text { Eigenvector } \\
6\end{array}$ & $\begin{array}{l}\text { Eigenvector } \\
7\end{array}$ \\
\hline Trade union & 0.291 & 0.440 & 0.220 & -0.735 & -0.008 & 0.364 & -0.022 \\
\hline $\begin{array}{l}\text { Works } \\
\text { council or } \\
\text { other } \\
\text { representation }\end{array}$ & 0.188 & 0.626 & 0.327 & 0.335 & 0.406 & -0.412 & 0.137 \\
\hline $\begin{array}{l}\text { Board } \\
\text { representation }\end{array}$ & 0.372 & 0.310 & -0.425 & 0.491 & -0.124 & 0.573 & -0.024 \\
\hline $\begin{array}{l}\text { Employee } \\
\text { survey }\end{array}$ & 0.372 & -0.167 & -0.630 & -0.278 & 0.537 & -0.261 & 0.063 \\
\hline $\begin{array}{l}\text { Suggestion } \\
\text { scheme }\end{array}$ & 0.499 & -0.184 & 0.102 & -0.006 & -0.470 & -0.220 & 0.661 \\
\hline Quality circle & 0.521 & -0.127 & 0.146 & 0.053 & -0.258 & -0.294 & -0.731 \\
\hline \begin{tabular}{l} 
Teamwork \\
\hline Eigenvalue
\end{tabular} & 0.288 & -0.490 & 0.486 & 0.161 & 0.493 & 0.410 & 0.060 \\
\hline $\begin{array}{l}\text { Proportion } \\
\text { explained } \\
\text { (cumulative) }\end{array}$ & 0.309 & 1.278 & 0.884 & 0.818 & 0.718 & 0.639 & 0.503 \\
\hline
\end{tabular}


Table 6 The probability of a broad-based financial participation scheme.

Probit marginal effects (z-values in parenthesis).

\begin{tabular}{|c|c|c|c|c|}
\hline & $\begin{array}{l}\text { Broad-based } \\
\text { profit-sharing } \\
\text { scheme }\end{array}$ & $\begin{array}{l}\text { Broad-based } \\
\text { equity scheme }\end{array}$ & $\begin{array}{l}\text { Broad- } \\
\text { based share } \\
\text { acquisition } \\
\text { plan }\end{array}$ & $\begin{array}{l}\text { Share } \\
\text { options } \\
\text { plans }\end{array}$ \\
\hline $\begin{array}{l}\text { Broad-based equity } \\
\text { scheme / broad- } \\
\text { based profit-sharing } \\
\text { scheme }\end{array}$ & $\begin{array}{l}0.118^{*} \\
(1.34)\end{array}$ & $\begin{array}{l}0.125^{*} \\
(1.77)\end{array}$ & $\begin{array}{l}0.212 * * \\
(2.41)\end{array}$ & $\begin{array}{l}0.124 \\
(1.52)\end{array}$ \\
\hline $\begin{array}{l}\text { General } \\
\text { participation }\end{array}$ & $\begin{array}{l}0.054^{* *} \\
(1.97) \\
\end{array}$ & $\begin{array}{l}-0.016 \\
(-0.56)\end{array}$ & $\begin{array}{l}0.019 \\
(0.56)\end{array}$ & $\begin{array}{l}-0.024 \\
(-0.76) \\
\end{array}$ \\
\hline $\begin{array}{l}\text { Contrast between } \\
\text { indirect } \\
\text { participation and } \\
\text { direct participation }\end{array}$ & $\begin{array}{l}0.054 \\
(1.52)\end{array}$ & $\begin{array}{l}-0.041 \\
(-1.19)\end{array}$ & $\begin{array}{l}-0.010 \\
(-0.23)\end{array}$ & $\begin{array}{l}-0.033 \\
(-0.89)\end{array}$ \\
\hline Netherlands & $\begin{array}{l}0.065 \\
(0.63) \\
\end{array}$ & $\begin{array}{l}-0.355^{* * *} \\
(-3.69)\end{array}$ & $\begin{array}{l}-0.471 * * * \\
(-4.85)\end{array}$ & $\begin{array}{l}-0.325 * * * \\
(-3.37)\end{array}$ \\
\hline France & $\begin{array}{l}0.550 * * * \\
(4.93)\end{array}$ & $\begin{array}{l}-0.207 \\
(-1.54)\end{array}$ & $\begin{array}{l}-0.282^{* *} \\
(-2.21)\end{array}$ & $\begin{array}{l}-0.152 \\
(-1.08)\end{array}$ \\
\hline Finland & $\begin{array}{l}0.171 \\
(1.31) \\
\end{array}$ & $\begin{array}{l}-0.434 * * * \\
(-4.11)\end{array}$ & $\begin{array}{l}-0.477 * * * \\
(-4.82) \\
\end{array}$ & $\begin{array}{l}-0.359 * * * \\
(-3.40)\end{array}$ \\
\hline Spain & $\begin{array}{l}-0.299 * * * \\
(-2.73)\end{array}$ & $\begin{array}{l}-0.513 * * * \\
(-4.47)\end{array}$ & $\begin{array}{l}-0.457 * * * \\
(-4.08)\end{array}$ & $\begin{array}{l}-0.462 * * * \\
(-4.36)\end{array}$ \\
\hline Germany & $\begin{array}{l}-0.103 \\
(-0.94) \\
\end{array}$ & $\begin{array}{l}-0.118 \\
(-1.00) \\
\end{array}$ & $\begin{array}{l}-0.343^{* * * *} \\
(-3.28) \\
\end{array}$ & $\begin{array}{l}-0.196^{*} \\
(-1.67) \\
\end{array}$ \\
\hline \multicolumn{5}{|l|}{ UK (omitted) } \\
\hline ICT & $\begin{array}{l}-0.041 \\
(-0.42)\end{array}$ & $\begin{array}{l}0.201 * * \\
(2.38)\end{array}$ & $\begin{array}{l}0.123 \\
(1.03) \\
\end{array}$ & $\begin{array}{l}0.285 * * * \\
(3.16)\end{array}$ \\
\hline Services & $\begin{array}{l}-0.034 \\
(-0.44) \\
\end{array}$ & $\begin{array}{l}-0.009 \\
(-0.12) \\
\end{array}$ & $\begin{array}{l}0.049 \\
(0.51) \\
\end{array}$ & $\begin{array}{l}-0.033 \\
(-0.39) \\
\end{array}$ \\
\hline \multicolumn{5}{|l|}{$\begin{array}{l}\text { Manufacturing } \\
\text { (omitted) }\end{array}$} \\
\hline $\begin{array}{l}\mathrm{Nr} \text { of employees (in } \\
\log \text { ) }\end{array}$ & $\begin{array}{l}0.055^{* * *} \\
(2.83)\end{array}$ & $\begin{array}{l}-0.048 * * * \\
(-2.61)\end{array}$ & $\begin{array}{l}-0.037 \\
(-1.55) \\
\end{array}$ & $\begin{array}{l}-0.051 * * \\
(-2.45) \\
\end{array}$ \\
\hline $\mathrm{Nr}$ of observations & 222 & 222 & 222 & 222 \\
\hline $\begin{array}{l}\text { Likelihood ratio } \\
\text { chi2 }\end{array}$ & $58.64 * * *$ & $38.65 * * *$ & $59.37 * * *$ & $39.27 * * *$ \\
\hline Pseudo R2 & 0.192 & 0.121 & 0.237 & 0.137 \\
\hline $\begin{array}{l}\text { Expected } \\
\text { probability }\end{array}$ & 0.350 & 0.611 & 0.506 & 0.502 \\
\hline
\end{tabular}

Significance levels: $* * *-1 \%, * *-5 \%, *-10 \%$. The expected probability was calculated by keeping the log of nr of employees at its mean and other variables at zero. 
Table $7 \quad$ Employee participation rates in financial participation by country

Mean, (standard deviation), and median percentages. Number of observations

\begin{tabular}{|l|l|l|l|l|l|l|l|}
\hline & Netherlands & France & UK & Finland & Spain & Germany & All \\
\hline Participation & 77.16 & 98.41 & 78.38 & 80.96 & 55 & 76.44 & 81.55 \\
rate, Profit- & $(34.90)$ & $(4.73)$ & $(24.33)$ & $(26.77)$ & $(63.64)$ & $(35.00)$ & $(29.01)$ \\
sharing & 98 & 100 & 85 & 97.50 & 55 & 100 & 100 \\
$\mathrm{~N}$ & $(31)$ & $(22)$ & $(24)$ & $(24)$ & $(2)$ & $(18)$ & $(121)$ \\
\hline Participation & 51.07 & 73.87 & 57.10 & 53.05 & 29.80 & 52.26 & 55.18 \\
rate, Equity & $(37.51)$ & $(27.71)$ & $(30.04)$ & $(33.12)$ & $(31.63)$ & $(32.26)$ & $(33.35)$ \\
plan & 50 & 75 & 55 & 50 & 20 & 50 & 56.00 \\
$\mathrm{~N}$ & $(42)$ & $(18)$ & $(43)$ & $(19)$ & $(5)$ & $(27)$ & $(154)$ \\
\hline Participation & 50.51 & 72.45 & 57.75 & 52.11 & 29.80 & 52.67 & 54.99 \\
rate, stock & $(37.90)$ & $(27.88)$ & $(31.06)$ & $(33.81)$ & $(31.63)$ & $(33.18)$ & $(33.95)$ \\
options & 50 & 70 & 57.5 & 45 & 20 & 50 & 56 \\
$\mathrm{~N}$ & $(39)$ & $(17)$ & $(38)$ & $(18)$ & $(5)$ & $(21)$ & $(138)$ \\
\hline Participation & 55.73 & 75.85 & 58.73 & 50.00 & 41.67 & 50.63 & 57.89 \\
rate, share & $(37.37)$ & $(27.06)$ & $(29.60)$ & $(38.59)$ & $(37.53)$ & $(28.45)$ & $(31.57)$ \\
acquisition & 50 & 80 & 60 & 40 & 20 & 41.5 & 58.5 \\
$\mathrm{~N}$ & $(11)$ & $(13)$ & $(41)$ & $(10)$ & $(3)$ & $(16)$ & $(94)$ \\
\hline
\end{tabular}

Notes:

Where respondents participate in options and share acquisition programmes we are unable to distinguish the separate participation rates in each.

Equity plans include stock appreciation rights and convertible bonds 
Table 8 The determinants of employee participation rates.

\section{OLS estimates (t-values in parenthesis)}

\begin{tabular}{|c|c|c|c|c|}
\hline & $\begin{array}{l}\text { (1) Participation } \\
\text { rate in PS scheme }\end{array}$ & $\begin{array}{l}\text { (2) Participation } \\
\text { rate in equity } \\
\text { scheme }\end{array}$ & $\begin{array}{l}\text { (3) Participation } \\
\text { rate in share } \\
\text { acquisition scheme }\end{array}$ & $\begin{array}{l}\text { (4) Participation } \\
\text { rate in stock } \\
\text { options scheme } \\
\end{array}$ \\
\hline $\begin{array}{l}\text { Participation rate } \\
\text { in equity / profit- } \\
\text { sharing scheme }\end{array}$ & $\begin{array}{l}0.14 \\
(1.56)\end{array}$ & $\begin{array}{l}0.09 \\
(1.56)\end{array}$ & $\begin{array}{l}0.11^{* *} \\
(2.17)\end{array}$ & $\begin{array}{l}0.11 \\
(1.78)\end{array}$ \\
\hline $\begin{array}{l}\text { General } \\
\text { participation }\end{array}$ & $\begin{array}{l}5.31 * * \\
(2.30)\end{array}$ & $\begin{array}{l}-1.52 \\
(-0.79)\end{array}$ & $\begin{array}{l}1.36 \\
(0.79)\end{array}$ & $\begin{array}{l}-1.93 \\
(-0.99)\end{array}$ \\
\hline $\begin{array}{l}\text { Contrast between } \\
\text { indirect } \\
\text { participation and } \\
\text { direct participation }\end{array}$ & $\begin{array}{l}2.52 \\
(0.86)\end{array}$ & $\begin{array}{l}-4.48^{*} \\
(-1.86)\end{array}$ & $\begin{array}{l}-2.04 \\
(-0.95)\end{array}$ & $\begin{array}{l}-4.36^{*} \\
(-1.79)\end{array}$ \\
\hline Netherlands & $\begin{array}{l}8.41 \\
(0.96)\end{array}$ & $\begin{array}{l}-25.58 * * * \\
(-3.65)\end{array}$ & $\begin{array}{l}-44.52 * * * \\
(-7.13)\end{array}$ & $\begin{array}{l}-23.06 \\
(-3.25)\end{array}$ \\
\hline France & $\begin{array}{l}55.61 * * * \\
(4.76)\end{array}$ & $\begin{array}{l}-2.58 \\
(-0.25)\end{array}$ & $\begin{array}{l}-13.34 \\
(-1.48)\end{array}$ & $\begin{array}{l}-1.37 \\
(-0.13)\end{array}$ \\
\hline Finland & $\begin{array}{l}14.61 \\
(1.35)\end{array}$ & $\begin{array}{l}-34.47 * * * \\
(-4.00)\end{array}$ & $\begin{array}{l}-47.12^{* * *} \\
(-6.14)\end{array}$ & $\begin{array}{l}-28.36^{* * * *} \\
(-3.26)\end{array}$ \\
\hline Spain & $\begin{array}{l}-26.36^{* *} \\
(-1.98) \\
\end{array}$ & $\begin{array}{l}-38.77 * * * \\
(-3.62)\end{array}$ & $\begin{array}{l}-36.64 * * * \\
(-3.85)\end{array}$ & $\begin{array}{l}-32.48 * * * \\
(-3.00)\end{array}$ \\
\hline Germany & $\begin{array}{l}-5.16 \\
(-0.51) \\
\end{array}$ & $\begin{array}{l}-5.62 \\
(-0.67) \\
\end{array}$ & $\begin{array}{l}-24.12^{* * * *} \\
(-3.25)\end{array}$ & $\begin{array}{l}-6.47 \\
(-0.77) \\
\end{array}$ \\
\hline \multicolumn{5}{|l|}{ UK (omitted) } \\
\hline ICT & $\begin{array}{l}-10.00 \\
(-1.12) \\
\end{array}$ & $\begin{array}{l}27.42 * * * \\
(3.88)\end{array}$ & $\begin{array}{l}12.28^{*} \\
(1.95)\end{array}$ & $\begin{array}{l}1.64 * * * \\
(4.43) \\
\end{array}$ \\
\hline Services & $\begin{array}{l}4.36 \\
(0.67) \\
\end{array}$ & $\begin{array}{l}1.01 \\
(0.19) \\
\end{array}$ & $\begin{array}{l}3.98 \\
(0.84) \\
\end{array}$ & $\begin{array}{l}0.91 \\
(0.17) \\
\end{array}$ \\
\hline \multicolumn{5}{|l|}{$\begin{array}{l}\text { Manufacturing } \\
\text { (omitted) }\end{array}$} \\
\hline $\begin{array}{l}\mathrm{Nr} \text { of employees } \\
\text { (in log) }\end{array}$ & $\begin{array}{l}3.76^{* *} \\
(2.39) \\
\end{array}$ & $\begin{array}{l}-2.50^{*} \\
(-1.92)\end{array}$ & $\begin{array}{l}-1.39 \\
(-1.20) \\
\end{array}$ & $\begin{array}{l}-2.54^{*} \\
(-1.93) \\
\end{array}$ \\
\hline Constant & $\begin{array}{l}-0.10 \\
(-0.01)\end{array}$ & $\begin{array}{l}64.53 * * * \\
(4.99)\end{array}$ & $\begin{array}{l}54.77 * * * \\
(4.76)\end{array}$ & $\begin{array}{l}57.54 * * * \\
(4.43)\end{array}$ \\
\hline Nr of observations & 207 & 207 & 207 & 207 \\
\hline F-test & $6.52 * * *$ & $5.38^{* * * *}$ & $7.75 * * *$ & $5.12 * * *$ \\
\hline Adjusted R2 & 0.228 & 0.190 & 0.265 & 0.18 \\
\hline
\end{tabular}

Significance levels: $* * *-1 \%, * *-5 \%, *-10 \%$. 
Table 9 The determinants of employee participation rates.

\section{OLS estimates ( $t$-values in parenthesis)}

\begin{tabular}{|c|c|c|c|c|}
\hline & $\begin{array}{l}\text { (5) Participation } \\
\text { rate in PS scheme }\end{array}$ & $\begin{array}{l}\text { (6) Participation } \\
\text { rate in equity } \\
\text { scheme }\end{array}$ & $\begin{array}{l}\text { (7) Participation in } \\
\text { stock acquisition } \\
\text { plan }\end{array}$ & $\begin{array}{l}\text { (8) Participation in } \\
\text { stock options plan }\end{array}$ \\
\hline $\begin{array}{l}\text { Participation rate } \\
\text { in equity / profit- } \\
\text { sharing scheme }\end{array}$ & $\begin{array}{l}0.01 \\
(0.09)\end{array}$ & $\begin{array}{l}0.14^{*} \\
(1.92)\end{array}$ & $\begin{array}{l}0.12^{*} \\
(1.72)\end{array}$ & $\begin{array}{l}0.19^{* *} \\
(2.53)\end{array}$ \\
\hline $\begin{array}{l}\text { General } \\
\text { participation }\end{array}$ & $\begin{array}{l}4.45 \\
(1.63)\end{array}$ & $\begin{array}{l}-0.56 \\
(-0.25)\end{array}$ & $\begin{array}{l}2.89 \\
(1.27)\end{array}$ & $\begin{array}{l}-2.48 \\
(-1.03)\end{array}$ \\
\hline $\begin{array}{l}\text { Contrast between } \\
\text { indirect } \\
\text { participation and } \\
\text { direct participation }\end{array}$ & $\begin{array}{l}1.52 \\
(0.45)\end{array}$ & $\begin{array}{l}-6.43^{* *} \\
(-2.37)\end{array}$ & $\begin{array}{l}-2.35 \\
(-0.85)\end{array}$ & $\begin{array}{l}-5.58^{*} \\
(-1.92)\end{array}$ \\
\hline Netherlands & $\begin{array}{l}2.99 \\
(0.29) \\
\end{array}$ & $\begin{array}{l}-8.08 \\
(-0.96) \\
\end{array}$ & $\begin{array}{l}-34.95^{* * *} \\
(-4.12)\end{array}$ & $\begin{array}{l}-13.39 \\
(-1.49) \\
\end{array}$ \\
\hline France & $\begin{array}{l}36.88 * * * \\
(2.64)\end{array}$ & $\begin{array}{l}21.90^{*} \\
(1.83)\end{array}$ & $\begin{array}{l}11.71 \\
(0.97)\end{array}$ & $\begin{array}{l}20.04 \\
(1.57)\end{array}$ \\
\hline Finland & $\begin{array}{l}7.57 \\
(0.59) \\
\end{array}$ & $\begin{array}{l}-7.67 \\
(-0.63) \\
\end{array}$ & $\begin{array}{l}-24.40 * * \\
(-1.99) \\
\end{array}$ & $\begin{array}{l}-7.63 \\
(-0.59) \\
\end{array}$ \\
\hline Spain & $\begin{array}{l}-43.41 * * \\
(-2.14) \\
\end{array}$ & $\begin{array}{l}-14.66 \\
(-0.86) \\
\end{array}$ & $\begin{array}{l}-8.39 \\
(-0.49) \\
\end{array}$ & $\begin{array}{l}-12.37 \\
(-0.68) \\
\end{array}$ \\
\hline Germany & $\begin{array}{l}-14.02 \\
(-1.23) \\
\end{array}$ & $\begin{array}{l}0.76 \\
(0.08)\end{array}$ & $\begin{array}{l}-11.37 \\
(-1.17)\end{array}$ & $\begin{array}{l}-3.68 \\
(-0.36)\end{array}$ \\
\hline \multicolumn{5}{|l|}{ UK (omitted) } \\
\hline ICT & $\begin{array}{l}-13.82 \\
(-1.41) \\
\end{array}$ & $\begin{array}{l}8.71^{* *} \\
(2.45) \\
\end{array}$ & $\begin{array}{l}14.99^{*} \\
(1.94)\end{array}$ & $\begin{array}{l}25.42 * * * \\
(3.11) \\
\end{array}$ \\
\hline Services & $\begin{array}{l}3.52 \\
(0.46) \\
\end{array}$ & $\begin{array}{l}-2.27 \\
(-0.35) \\
\end{array}$ & $\begin{array}{l}4.68 \\
(0.72) \\
\end{array}$ & $\begin{array}{l}-2.72 \\
(-0.40) \\
\end{array}$ \\
\hline \multicolumn{5}{|l|}{$\begin{array}{l}\text { Manufacturing } \\
\text { (omitted) }\end{array}$} \\
\hline $\begin{array}{l}\text { Nr of employees } \\
\text { (in log) }\end{array}$ & $\begin{array}{l}3.35^{*} \\
(1.85)\end{array}$ & $\begin{array}{l}-3.48^{* *} \\
(-2.36)\end{array}$ & $\begin{array}{l}-2.02 \\
(-1.36)\end{array}$ & $\begin{array}{l}-3.88^{* *} \\
(-2.46)\end{array}$ \\
\hline $\begin{array}{l}\text { Employee } \\
\text { participation in the } \\
\text { scheme design } \\
(1-5 \text { scale })\end{array}$ & $\begin{array}{l}8.97 * * * \\
(2.86)\end{array}$ & $\begin{array}{l}1.61 \\
(0.53)\end{array}$ & $\begin{array}{l}0.64 \\
(0.21)\end{array}$ & $\begin{array}{l}-2.69 \\
(-0.83)\end{array}$ \\
\hline $\begin{array}{l}\text { Performance at } \\
\text { adoption above } \\
\text { industry average }\end{array}$ & $\begin{array}{l}1.11 \\
(0.16)\end{array}$ & $\begin{array}{l}-5.21 \\
(-0.91)\end{array}$ & $\begin{array}{l}-2.44 \\
(-0.42)\end{array}$ & $\begin{array}{l}-4.81 \\
(-0.78)\end{array}$ \\
\hline $\begin{array}{l}\text { Employee tax } \\
\text { reliefs }\end{array}$ & - & $\begin{array}{l}12.29^{*} \\
(1.72)\end{array}$ & $\begin{array}{l}15.99^{* *} \\
2.21\end{array}$ & $\begin{array}{l}9.00 \\
(1.18)\end{array}$ \\
\hline $\begin{array}{l}\text { Company tax } \\
\text { reliefs }\end{array}$ & - & $\begin{array}{l}2.84 \\
(0.40) \\
\end{array}$ & $\begin{array}{l}7.64 \\
(1.06)\end{array}$ & $\begin{array}{l}3.09 \\
(0.41) \\
\end{array}$ \\
\hline Constant & $\begin{array}{l}3.61 \\
(0.17)\end{array}$ & $\begin{array}{l}64.44 * * * \\
(3.89) \\
\end{array}$ & $\begin{array}{l}42.90 * * \\
(2.56)\end{array}$ & $\begin{array}{l}71.26 * * * \\
(4.02) \\
\end{array}$ \\
\hline Nr of observations & 158 & 123 & 123 & 123 \\
\hline F-test & $4.50^{* * *}$ & $3.07 * * *$ & $4.95 * * *$ & $3.11 * * *$ \\
\hline Adjusted R2 & 0.225 & 0.203 & 0.327 & 0.260 \\
\hline
\end{tabular}

Significance levels: *** - 1\%,**-5\%,*-10\%. 
Appendix One The use of indirect and direct participation: frequency and relative frequency (in percentages)

\begin{tabular}{|c|c|c|c|c|c|c|c|}
\hline & $\begin{array}{l}\text { Netherlands } \\
\text { (69) }\end{array}$ & $\begin{array}{l}\text { France } \\
(29-30)\end{array}$ & $\begin{array}{l}\text { UK } \\
(55)\end{array}$ & $\begin{array}{l}\text { Finland } \\
\text { (41) }\end{array}$ & $\begin{array}{l}\text { Spain } \\
(16)\end{array}$ & $\begin{array}{l}\text { Germany } \\
(34)\end{array}$ & $\begin{array}{l}\text { All } \\
(244-5)\end{array}$ \\
\hline \multicolumn{8}{|l|}{$\begin{array}{c}\text { Indirect } \\
\text { participation }\end{array}$} \\
\hline $\begin{array}{l}\text { Trade union } \\
\text { committee }\end{array}$ & $\begin{array}{l}14 \\
(20.3 \%)\end{array}$ & $\begin{array}{l}16 \\
(53.3 \%)\end{array}$ & \begin{tabular}{|l|}
23 \\
$(41.8 \%)$ \\
\end{tabular} & $\begin{array}{l}24 \\
(58.5 \%) \\
\end{array}$ & \begin{tabular}{|l|}
7 \\
$(43.8 \%)$ \\
\end{tabular} & $\begin{array}{l}11 \\
(32.4 \%) \\
\end{array}$ & $\begin{array}{l}95 \\
(38.8 \%) \\
\end{array}$ \\
\hline $\begin{array}{l}\text { Board } \\
\text { representation }\end{array}$ & $\begin{array}{l}2 \\
(2.9 \%)\end{array}$ & $\begin{array}{l}10 \\
(33.3 \%)\end{array}$ & \begin{tabular}{|l}
11 \\
$(20.0 \%)$ \\
\end{tabular} & $\begin{array}{l}16 \\
(39.0 \%)\end{array}$ & $\begin{array}{l}1 \\
(6.3 \%)\end{array}$ & $\begin{array}{l}23 \\
(67.7 \%)\end{array}$ & $\begin{array}{l}63 \\
(25.7 \%)\end{array}$ \\
\hline $\begin{array}{l}\text { Other form of } \\
\text { representation } \\
\text { (incl. works } \\
\text { councils and } \\
\text { joint } \\
\text { consultation } \\
\text { committees) }\end{array}$ & $\begin{array}{l}54 \\
(78.3 \%)\end{array}$ & $\begin{array}{l}26 \\
(86.7 \%)\end{array}$ & \begin{tabular}{|l|}
38 \\
$(69.1 \%)$
\end{tabular} & $\begin{array}{l}25 \\
(61.0 \%)\end{array}$ & $\begin{array}{l}14 \\
(87.5 \%)\end{array}$ & $\begin{array}{l}29 \\
(85.3 \%)\end{array}$ & $\begin{array}{l}186 \\
(75.9 \%)\end{array}$ \\
\hline $\begin{array}{l}\text { Average } \\
\text { number of } \\
\text { indirect } \\
\text { participation } \\
\text { practices }\end{array}$ & $\begin{array}{l}1.01 \\
(0.68)\end{array}$ & $\begin{array}{l}1.73 \\
(0.94)\end{array}$ & $\begin{array}{l}1.31 \\
(0.88)\end{array}$ & $\begin{array}{l}1.59 \\
(1.14)\end{array}$ & $\begin{array}{l}1.38 \\
(0.72)\end{array}$ & $\begin{array}{l}1.85 \\
(0.96)\end{array}$ & $\begin{array}{l}1.40 \\
(0.93)\end{array}$ \\
\hline $\begin{array}{l}\text { Number of } \\
\text { firms having } \\
\text { at least one } \\
\text { indirect } \\
\text { participation } \\
\text { practice }\end{array}$ & $\begin{array}{l}54 \\
(78.3 \%)\end{array}$ & $\begin{array}{l}27 \\
(90.0 \%)\end{array}$ & \begin{tabular}{|l|}
44 \\
$(80.0 \%)$
\end{tabular} & $\begin{array}{l}30 \\
(73.2 \%)\end{array}$ & \begin{tabular}{|l|}
15 \\
$(93.7 \%)$
\end{tabular} & $\begin{array}{l}30 \\
(89.2 \%)\end{array}$ & $\begin{array}{l}200 \\
(82.6 \%)\end{array}$ \\
\hline \multicolumn{8}{|l|}{$\begin{array}{l}\text { Direct } \\
\text { participation }\end{array}$} \\
\hline $\begin{array}{l}\text { Employee } \\
\text { survey }\end{array}$ & $\begin{array}{l}18 \\
(26.1 \%)\end{array}$ & $\begin{array}{l}3 \\
(10.0 \%)\end{array}$ & \begin{tabular}{|l|}
32 \\
$(58.2 \%)$
\end{tabular} & $\begin{array}{l}25 \\
(63.4 \%)\end{array}$ & $\begin{array}{l}2 \\
(12.5 \%)\end{array}$ & $\begin{array}{l}12 \\
(35.3 \%)\end{array}$ & $\begin{array}{l}93 \\
(38.0 \%)\end{array}$ \\
\hline $\begin{array}{l}\text { Suggestion } \\
\text { scheme }\end{array}$ & $\begin{array}{l}18 \\
(26.1 \%)\end{array}$ & $\begin{array}{l}0 \\
(0.0 \%)\end{array}$ & \begin{tabular}{|l}
26 \\
$(47.3 \%)$
\end{tabular} & $\begin{array}{l}30 \\
(73.2 \%)\end{array}$ & $\begin{array}{l}9 \\
(56.3 \%)\end{array}$ & $\begin{array}{l}19 \\
(55.9 \%)\end{array}$ & $\begin{array}{l}102 \\
(41.6 \%)\end{array}$ \\
\hline Quality circle & $\begin{array}{l}16 \\
(23.2 \%)\end{array}$ & $\begin{array}{l}1 \\
(3.3 \%)\end{array}$ & \begin{tabular}{|l}
20 \\
$(36.4 \%)$
\end{tabular} & $\begin{array}{l}21 \\
(51.2 \%)\end{array}$ & $\begin{array}{l}5 \\
(31.3 \%) \\
\end{array}$ & $\begin{array}{l}15 \\
(44.1 \%)\end{array}$ & $\begin{array}{l}78 \\
(31.8 \%)\end{array}$ \\
\hline Teamwork & $\begin{array}{l}25 \\
(36.2 \%) \\
\end{array}$ & \begin{tabular}{|l|}
3 \\
$(10.0 \%)$ \\
\end{tabular} & \begin{tabular}{|l|}
13 \\
$(23.6 \%)$ \\
\end{tabular} & $\begin{array}{l}25 \\
(61.0 \%) \\
\end{array}$ & $\begin{array}{l}1 \\
(6.3 \%) \\
\end{array}$ & $\begin{array}{l}6 \\
(17.7 \%) \\
\end{array}$ & $\begin{array}{l}73 \\
(29.8 \%) \\
\end{array}$ \\
\hline $\begin{array}{l}\text { Average } \\
\text { number of } \\
\text { direct } \\
\text { participation } \\
\text { practices }\end{array}$ & $\begin{array}{l}1.12 \\
(1.24)\end{array}$ & $\begin{array}{l}0.23 \\
(0.63)\end{array}$ & $\begin{array}{l}1.65 \\
(1.19)\end{array}$ & $\begin{array}{l}2.49 \\
(1.16)\end{array}$ & $\begin{array}{l}1.06 \\
(0.85)\end{array}$ & $\begin{array}{l}1.53 \\
(1.28)\end{array}$ & $\begin{array}{l}1.41 \\
(1.30)\end{array}$ \\
\hline $\begin{array}{l}\text { Number of } \\
\text { firms having } \\
\text { at least one } \\
\text { direct } \\
\text { participation } \\
\text { practice }\end{array}$ & $\begin{array}{l}40 \\
(58.0 \%)\end{array}$ & $\begin{array}{l}5 \\
(16.7 \%)\end{array}$ & $\begin{array}{l}46 \\
(83.6 \%)\end{array}$ & $\begin{array}{l}38 \\
(92.7 \%)\end{array}$ & $\begin{array}{l}11 \\
(68.8 \%)\end{array}$ & $\begin{array}{l}24 \\
(70.6 \%)\end{array}$ & $\begin{array}{l}164 \\
(67.0 \%)\end{array}$ \\
\hline
\end{tabular}




\section{REFERENCES}

Addison, J. and C. Belfield (2000). 'The impact of financial participation and employee involvement on financial performance: A re-estimation using the 1998 WERS', Scottish Journal of Political Economy, 47: 571-583.

Ben-Ner, A. and D.Jones (1995) 'Employee Participation, Ownership and Productivity: A Theoretical Framework', Industrial Relations, 34: 532-555.

Ben-Ner, A., W. A. Burns, G.Dow, and L.Putterman (2000) 'Employee Ownership: An Empirical Exploration', pp. 194-240 in M. Blair and T. Kochan (eds.): The New Relationship: Human Capital in the American Corporation, Washington, D.C.: Brookings.

Blinder, A. (1990) Paying for Productivity: A Look at the Evidence, Washington D.C.: Brookings.

Breen, R.(1996) Regression Models: Censored, Sample Selected, and Truncated Data, Quantitative Applications in the Social Sciences Nr 111, Thousand Oaks, CA: Sage.

Buschak, W. (2002) 'Financial participation for employees in the European Union - a pragmatic view' Transfer 8 (1): 76-82.

Carstensen, V., G.Gerlach, and O.Hubler (1995) 'Profit sharing in German firms', in F.buttler, W.Franz, R. Schettkat, and D. Soskice (eds.) Institutional Frameworks and Labor Market Performance: Comparative Views on the US and German Economies. London: Routledge.

Commission of the European Communities (2002) Communication from the Commission to the council, the European Parliament, the Economic and Social Committee and the Committee of the Regions: on a Framework for the Promotion of Employee Financial Participation. Brussels: Commission of the European Communities, COM (2002) 364 final.

Doucouliagos, C. (1995) 'Worker Participation and Productivity in Labor-Managed and Participatory Capitalist Firms: A Meta-Analysis', Industrial and Labor Relations Review, 49 (1): 58-77.

Drago, R. and J. Heywood (1995) 'The choice of payment schemes: Australian establishment data', Industrial Relations, 34: 507-531.

Dube, A.and R. Freeman (2001) 'Shared Compensation Systems and DecisionMaking in the US Job Market', in Incomes and Productivity in North America: Papers from the 2000 Seminar, Washington, DC: Commission for Labor Cooperation. 
Dunteman, G. (1989) Principal Components Analysis, Quantitative Applications in the Social Sciences Nr 69, Thousand Oaks, CA: Sage.

Eaton, A. and P. Voos. (1992). 'Unions and contemporary innovations in work organisation, compensation, and employee participation' in L.Mishel and P.Voos (eds.) Unions and Economic Competitiveness.

Fernie, S. and D. Metcalf (1995) 'Participation, Contingent Pay, Representation and Workplace Performance: Evidence from Great Britain', British Journal of Industrial Relations, 33 (3): 379-415.

Festing, M., Y. Groening, R. Pabst, and W. Weber (1999) 'Financial participation in Europe - determinants and outcomes' Economic and Industrial Democracy 20: 295329.

Greene, W. (2000) Econometric Analysis, New York: Macmillan (4th ed.).

Gregg, P.and S. Machin (1988) 'Unions and the incidence of performance linked pay schemes in Britain' International Journal of Industrial Organisation, 6 (1): 91-109.

Heywood, J., O. Hubler, and U. Jirjahn (1997) 'Use of variable payment schemes: evidence from Germany’, Kyklos, 51(2): 237-58.

Huselid, M. (1995) 'The impact of human resourcemanagement practices on turnover, producitivyt, and corporate financial performance' Academy of Management Journal 38 (3): 635-672.

Ichniowski, C., K. Shaw, and G. Prennushi (1997) 'The effects of Human Resource Management Practices on Productivity: A Study of Steel Finishing Lines', American Economic Review, 87 (3): 291-322.

Ittner, C., R. Lambert, and D. Larcker (2003) 'The Structure and Performance of Equity Grants to Employees of New Economy Firms', Journal of Accounting and Economics 34, (1-3), 89-127.

Jones, D., P. Kalmi and M. Mäkinen (2004) 'The Incidence of Broad-Based and Selective Stock Option Schemes: Evidence From Finland', paper presented in the ASSA meetings, San Diego, January 2004.

Jones, D. and T. Kato (1995) 'The Productivity Effects of Employee StockOwnership Plans and Bonuses: Evidence from Japanese Panel Data', American Economic Review, 85 (3): 391-414.

Jones, D., T. Kato and J. Pliskin (1997) 'Profit Sharing and Gainsharing: A Review of Theory, Incidence, and Effects', in D. Lewin, D. Mitchell, and M. Zaidi (eds.) The Human Resource Management Handbook, part I, Greenwich, CT: JAI Press.

Kandel, E. and E. Lazear (1992) 'Peer Pressure in Partnerships', Journal of Political Economy, 100: 801-17. 
Kruse, D. (1996). 'Why do firms adopt profit-sharing and employee ownership plans? British Journal of Industrial Relations', 34: 515-538.

Kruse, D. and J. Blasi (1997) 'Employee Ownership, Employee Attitudes, and Firm Performance: A Review of the Evidence', in D. Lewin, D. Mitchell, and M. Zaidi (eds.) The Human Resource Management Handbook, part I, Greenwich, CT: JAI Press.

Laursen, K. and N. Foss (2003) 'New Human Resource Management Practices, Complementarities and the Impact on Innovation Performance', Cambridge Journal of Economics, 27 (2): 243-63.

Levine, D. (1995) Reinventing the Workplace: How Business and Employees Can Both Win, Washington, D.C.: Brookings.

Levine, D. and L.D'Andrea Tyson (1990) 'Participation, productivity, and the firm's environment' in A.Blinder (ed.) Paying for Productivity: A Look at the Evidence, Washington D.C.: Brookings.

MacDuffie, J. (1995) 'Human Resource Bundles and Manufacturing Performance: Organizational Logic and Flexible Production Systems in the World Auto Industry', Industrial and Labor Relations Review, 48:197-221.

McNabb, R. and K. Whitfield (1998). 'The impact of financial participation and employee involvement on financial performance'. Scottish Journal of Political Economy, 45: 171-187.

Oyer, P. (20020 'Why do firms use incentives that have no incentive effects?' Stanford University: unpublished mimeo.

Pendleton, A. (1997) 'Characteristics of workplaces with financial participation: evidence from the WIRS' Industrial Relations Journal, 28: 103-119.

Pendleton, A., Poutsma, E., Ommeren, J. van and Brewster, C. (2001). Employee share ownership and profit sharing in the European Union. Dublin: European Foundation.

Pendleton, A., Poutsma, E., Ommeren, J. van and Brewster, C. (2003). 'The Incidence and Determinants of Employee Share Ownership and Profit Sharing in Europe' in T. Kato and J. Pliskin, (eds.), The Determinants of the Incidence and Effects of Participatory Organisations. (Advances of the Economic Analysis of Participatory and Labor Management, Volume 7). Oxford: Elseviers Science ltd..

Pérotin, V. and A. Robinson (2003) Employee Participation of Profit and Ownership: A Review of Issues and Evidence, Luxembourg: European Parliament.

Poutsma, E. (2001): Recent Trends in Employee Financial Participation in the European Union, Dublin: European Foundation for the Improvement of Living and Working Conditions. 
Poutsma, E. and W. deNijs (2003). ,Broad-based employee financial participation in the European Union'. International Journal of Human Resource Management, 14: 863-892.

Poutsma, E. and F. Huijgen (1999). ,European diversity in the use of participation schemes.' Economic and Industrial Democracy, 20: 197-223.

Union of Industrial and Employers' Confederations (UNICE) (2002) Financial Participation of Employees in the European Union: UNICE Position. Brussels: UNICE.

Weitzman, M. and D. Kruse (1990) 'Profit-Sharing and Productivity', in A. Blinder (ed.) Paying for Productivity: A Look at the Evidence, Washington D.C.: Brookings.

\footnotetext{
${ }^{\mathrm{i}}$ See for instance the recent European commission (2002) communication. Prior to that, EU has published e.g. two PEPPER reports and Community Recommendation in 1991.

${ }^{1 i}$ Given that information was being collected at corporate level from large, often diversified, companies, we also expected that such a measure would be unreliable.

${ }^{\text {iii }}$ Kurtosis and skewness statistics indicate that the distribution is clustered with a long right hand tail

iv The co-incidence of profit-sharing schemes and equity schemes may also be caused by different pay systems for different occupational groups, e.g. stock options for managers and profit-sharing for the entire personnel. However, we can control this to some extent, since we have information on participation rates.

${ }^{v}$ Alternatively, we could have used the bivariate probit model, where the probabilities for these two outcomes are estimated simultaneously by assuming that the disturbance terms in these equations are correlated (see Greene 2000, 849-56). The results from the bivariate probit models turned out to be similar to univariate probit models. Since the coefficients are easier to interpret in the univariate model, we report those in the paper. The bivariate results are available upon request.

${ }^{\text {vi }}$ The marginal effects of dummy variables are easier to interpret, when they are evaluated at zero (rather than at sample means). The participation indices are continuous, but they are standardised to have mean zero and standard deviation of one.

${ }^{\text {vii }}$ We have also checked the results by using the summated participation indices from Table 5 as explanatory variables. Overall, the results are quite consistent with the principal components approach.

viii The sample mean of this variable is 7.59 and standard deviation 2.28.

${ }^{i x}$ It is widely suggested that correlations between financial participation and superior company performance reflect a reverse causality to that stipulated in studies of performance effects (e.g. Weitzman and Kruse, 1990)

${ }^{\mathrm{x}}$ An alternative would be use models for censored or sample-selected data, such as tobit models or Heckman-type selection models (see e.g. Breen, 1996). However, these approaches are also sensitive to statistical problems. Probably due to the fact that most observations in profit-sharing equation are concentrated to the ends of the distribution, the standard two-limit tobit model produces implausibly large coefficients. In turn, Heckman-type selection models are quite sensitive to the assumption that the selection process is correctly specified. This assumption is not easily met with our data, which involves selection in two margins. Furthermore, our dependent variable is not censored in the sense that the values of dependent variable would not be observed for some observations, rather there are natural boundaries for these values. Partly for the ease of interpreting the OLS coefficients and partly for the lack of obvious solutions to the statistical problem, we go on to use the OLS, but remind the reader to be careful in interpreting the coefficients.
} 